Article

\title{
Direct Dehydrogenative Coupling of Alcohols with Hydrosilanes Promoted by Sodium tri(sec-butyl)borohydride
}

\author{
Maciej Skrodzki ${ }^{1,2}\left(\mathbb{D}\right.$, Maciej Zaranek ${ }^{1,2, * \mathbb{D}}$, Samanta Witomska ${ }^{1,2}$ and Piotr Pawluc ${ }^{1,2, *}$ \\ 1 Faculty of Chemistry, Adam Mickiewicz University in Poznań, Umultowska 89B, 61-614 Poznań, Poland; \\ maciej.skrodzki@amu.edu.pl (M.S.); samanta.witomska@amu.edu.pl (S.W.) \\ 2 Center for Advanced Technology, Adam Mickiewicz University in Poznań, Umultowska 89C, \\ 61-614 Poznań, Poland \\ * $\quad$ Correspondence: m.zaranek@amu.edu.pl (M.Z); piotr.pawluc@amu.edu.pl (P.P.); Tel.: +48-61-829-1700 (P.P)
}

Received: 13 November 2018; Accepted: 29 November 2018; Published: 4 December 2018

\begin{abstract}
Alkoxysilanes find application in many areas of chemistry ranging from research-scale organic synthesis to multi-ton production of materials. Classically, they are obtained in stoichiometric reaction of alcoholysis of chlorosilanes, however, recent years brought development in the field of direct dehydrogenative coupling of hydrosilanes with alcohols, which is a more atom-economic and benign alternative to the former process. In this paper, we report the use of sodium tri(sec-butyl)borohydride as a convenient promoter of this reaction. Exemplary syntheses carried out under mild conditions and without additional solvents, followed by very easy work-up procedure, show excellent potential for application of so devised catalytic system.
\end{abstract}

Keywords: alkoxysilanes; dehydrogenative coupling; trialkylborohydrides; solvent-free

\section{Introduction}

Alkoxysilanes constitute a group of compounds widely used in materials science as precursors of polymers [1], silica-based mesoporous materials [2-4], and surface coatings [5,6], in particular as silane coupling agents [7-9]. In organic chemistry, alkoxysilanes are often referred to as silyl ethers and are a widely used class of protecting groups for alcohols $[10,11]$, while silyl ethers of enolates are a set of convenient nucleophilic reagents [12].

Classical method of synthesis of alkoxysilanes relies mostly on the reaction of alcohols with chlorosilanes in the presence of a base and, sometimes, a silyl transfer agent [13,14]. Over the years, direct dehydrogenative coupling of alcohols with hydrosilanes emerged as a green, halogen-free alternative to the former approach. At the moment, it can be catalyzed by a wide range of compounds including both transition metal complexes [15-30] and simple inorganics and organocatalysts [31-35]. As the only byproduct of these reaction is molecular hydrogen, they are also considered chemical storage of this element [36], whose capacity greatly varies with the silane being used and can be as high as over $4 \mathrm{wt} \%$ [16].

Our interest in this reaction stems from the observation made during a previous study on trialkylborohydride-catalyzed hydrosilylation, especially as triethylborohydrides are widely used as additives in various other catalytic systems [37]. Then, we noticed that attempts to hydrosilylate 2-allyloxyethanol were unsuccessful, leading only to complete transformation of hydroto alkoxysilanes (Scheme 1). 


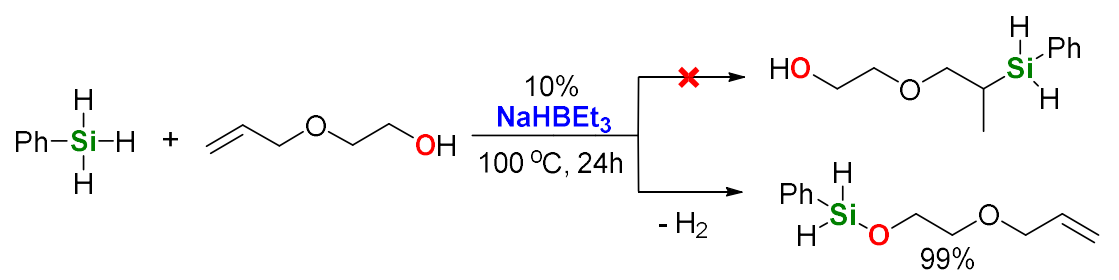

Scheme 1. The reaction of phenylsilane with 2-allyloxyethanol in the presence of sodium triethylborohydride.

An interesting point was if this side reaction could be further exploited and applied to a wider range of silanes and alcohols as possible method in organic synthesis.

\section{Results and Discussion}

At first, the usability of different alkali metal trialkylborohydrides was examined in a model reaction of benzyl alcohol 1 with dimethylphenylsilane $\mathbf{2}$ (Table 1). This reaction leads to one possible alkoxysilane 3 . Table 1 summarizes the results of optimization ran on 1-mmol scale.

Table 1. Results of optimization of dehydrogenative coupling of $\mathbf{1}$ with 2 using various trialkylborohydride salts as promoters ${ }^{1}$.

\begin{tabular}{|c|c|c|c|c|}
\hline Entry & {$\left[\mathrm{MHBR}_{3}\right]$} & Solvent, $c$ of 2 & $\mathrm{~T}\left[{ }^{\circ} \mathrm{C}\right]$ & Conv. of $2^{2}$ \\
\hline 1 & $\mathrm{NaHBEt}_{3}$ & Neat & RT & 17 \\
\hline 2 & $\mathrm{LiHBEt}_{3}$ & Neat & RT & 26 \\
\hline 3 & $\mathrm{KHBEt}_{3}$ & Neat & RT & 31 \\
\hline 4 & & Neat & 40 & 66 \\
\hline 5 & $\mathrm{NaHB}(s-\mathrm{Bu})_{3}$ & Neat & RT & 57 \\
\hline 6 & & Neat & 40 & 100 \\
\hline 7 & & $\mathrm{THF}, 1 \mathrm{M}$ & RT & 11 \\
\hline 8 & & Toluene, 1M & RT & 55 \\
\hline 9 & & Neat & RT & $69^{3}$ \\
\hline 10 & & Neat & 40 & $100^{4}$ \\
\hline
\end{tabular}

Notes: ${ }^{1}$ reaction conditions: [1]:[2]:[MHBR $]=1: 1: 0.1$, neat, RT, $20 \mathrm{~h}^{2}{ }^{2}$ determined by GC using $100 \mu \mathrm{L}$ of decane as reference; ${ }^{3}$ using $5 \%$ of borohydride; ${ }^{4}$ conversion after $1 \mathrm{~h}$.

The initial trial with sodium triethylborohydride (entry 1) turned out to be not as successful as the ones with the other trialkylborohydrides among which sodium tri(sec-butyl)borohydride has proven to be the best, giving complete conversion of 2 even in $1 \mathrm{~h}$ (entry 10). Further, we decided to use no solvent, as at room temperature the reaction carried out in solution was slower (entries 5 vs. 7 \& 8).

In the above-optimized conditions, we investigated the scope of this reaction, using various aliphatic and aromatic alcohols as well as selected primary, secondary and tertiary silanes. The results are presented in Table 2. 
Table 2. Substrate scope of $\mathrm{NaHB}(s-\mathrm{Bu})_{3}$ _promoted dehydrogenative coupling of silanes with alcohols ${ }^{1}$.

\begin{tabular}{|c|c|c|c|c|c|}
\hline$\#$ & Silane & Alcohol & Product & $\mathrm{t} / h^{2}$ & Isol. Yield \\
\hline 1 & $\mathrm{Me}_{2} \mathrm{PhSiH}$ & Benzyl alcohol & & $1 \mathrm{~h}$ & $98 \%$ \\
\hline 2 & & Ethanol & & $3 \mathrm{~min}$ & $93 \%$ \\
\hline 3 & & Methanol & & $10 \mathrm{~min}$ & $86 \%$ \\
\hline 4 & & 2-Allyloxyethanol & & $48 \mathrm{~h}$ & $86 \%$ \\
\hline $5^{3}$ & & 4-Bromobenzyl alcohol & & $24 \mathrm{~h}$ & $46 \%$ \\
\hline $6^{3}$ & & 4-Methylbenzyl alcohol & & $6 \mathrm{~h}$ & $94 \%$ \\
\hline $7^{3}$ & & 4-Fluorobenzyl alcohol & & $6 \mathrm{~h}$ & $86 \%$ \\
\hline $8^{3}$ & & 1-Cyclopropylethanol & & $4 \mathrm{~h}$ & $98 \%$ \\
\hline $9^{3}$ & & 3-Butyn-1-ol & & $24 \mathrm{~h}$ & $99 \%$ \\
\hline $10^{4,5}$ & $\mathrm{Ph}_{2} \mathrm{SiH}_{2}$ & Ethanol & & $3 \mathrm{~min}$ & $93 \%$ \\
\hline $11^{4,6}$ & & Benzyl alcohol & & $24 \mathrm{~h}$ & $97 \%$ \\
\hline $12^{4,6}$ & & Hexan-1-ol & & $24 \mathrm{~h}$ & $99 \%$ \\
\hline $13^{4}$ & & Cyclohexanol & & $1 \mathrm{~h}$ & $88 \%$ \\
\hline 14 & $\mathrm{MePh}_{2} \mathrm{SiH}$ & Ethanol & & $48 \mathrm{~h}$ & $96 \%$ \\
\hline 15 & & Benzyl alcohol & & $48 \mathrm{~h}$ & $93 \%$ \\
\hline 16 & & 2-Allyloxyethanol & & $48 \mathrm{~h}$ & $98 \%$ \\
\hline $17^{4}$ & $\mathrm{PhSiH}_{3}$ & Cyclohexanol & & $1 \mathrm{~h}$ & $89 \%$ \\
\hline
\end{tabular}


Table 2. Cont.

\begin{tabular}{|c|c|c|c|c|c|}
\hline$\#$ & Silane & Alcohol & Product & $\mathrm{t} / h^{2}$ & Isol. Yield \\
\hline $18^{4}$ & & 2-Allyloxyethanol & & $1 \mathrm{~h}$ & $99 \%$ \\
\hline $19^{3}$ & $i-\operatorname{Pr}_{3} \mathrm{SiH}$ & Methanol & & $\begin{array}{c}72 \text { h, } 67 \% \\
\text { conv. }\end{array}$ & - \\
\hline
\end{tabular}

Notes: ${ }^{1}$ general conditions: $\left[\mathrm{SiH}_{\mathrm{n}}\right]:[\mathrm{OH}]:\left[\mathrm{NaHB}(s-\mathrm{Bu})_{3}\right]=1: n: 0.1$, no additional solvent, $40{ }^{\circ} \mathrm{C} ;{ }^{2}$ time needed for complete conversion of substrates; ${ }^{3}$ reaction at $65{ }^{\circ} \mathrm{C} ;{ }^{4}$ reaction at room temperature; ${ }^{5}$ using $2 \mathrm{~mol} \%$ of $\operatorname{NaHB}(s-\mathrm{Bu})_{3} ;{ }^{6}$ using $5 \mathrm{~mol} \%$ of $\mathrm{NaHB}(s-\mathrm{Bu})_{3}$.

As follows from the results presented in Table 2, all used silanes and alcohols can be efficiently coupled with the aid of sodium tri(sec-butyl)borohydride, however, some substrates require either higher reaction temperatures or prolonged reaction time, which indicates a visible steric effect mostly of the silane. Simple aliphatic alcohols such as ethanol and methanol reacted efficiently with diphenylsilane and dimethylphenylsilane to give the corresponding alkoxysilanes in good yields $(86-96 \%)$ in a few minutes at room temperature (Table 2, entry $2-3,10)$, even with reduced $\mathrm{NaHB}(s-\mathrm{Bu})_{3}$ loading (Table 2, entry 10), however, silylation of ethanol by more sterically hindered methyldiphenylsilane required a longer reaction time $(48 \mathrm{~h})$. Similarly, diphenylmethylsilane seems to be less reactive in the reactions with benzyl alcohol derivatives than dimethyphenylsilane. Allyl- (Table 2, entries 4, 16, 18) and propargyl alcohol derivatives (Table 2, entry 9) can be efficiently O-silylated by primary and tertiary aromatic silanes with excellent chemoselectivity, which is surprising in view of our recent reports on the reactivity of allyl glycidyl ether and terminal alkynes in sodium triethylborohydride-mediated hydrosilylation [37] or dehydrogenative silylation reactions [38]. All compounds were isolated by extremely simple protocol employing precipitation of the remainders of catalyst with hexane, filtration through a $0.45 \mu \mathrm{m}$ syringe filter and evaporation of the solvent to give very high yields (up to $99 \%$, average $91 \%$ ). The structures of the products were confirmed by the ${ }^{1} \mathrm{H}$ and ${ }^{13} \mathrm{C}$ NMR spectra of isolated compounds (see Supporting Information). The limitation of this reaction system concerns its inapplicability to trialkylsilanes, such as triisopropylsilane, in whose presence a conversion of $67 \%$ was observed only in the reaction with methanol after $72 \mathrm{~h}$ of heating at $65^{\circ} \mathrm{C}$ (Table 2, entry 19). Other trialkylsilanes e. g. triethylsilane or (t-butyl)dimethylsilane appear to be unreactive in the reactions with aliphatic and aromatic alcohols in the conditions applied.

In general, this protocol provides very good chemoselectivity towards dehydrogenative coupling of alcohol with silane and no other processes were observed. Halogen substituents were also preserved, which is important from the point of view of possible subsequent functionalization. What is also remarkable, the nature of generated active catalyst must be milder than an alkoxide, as potentially dangerous redistribution of phenylsilane with evolution of gaseous pyrophoric $\mathrm{SiH}_{4}$ (Scheme 2) was not observed. This reaction was reported to occur in basic conditions $[39,40]$, especially in the presence of alkoxides.

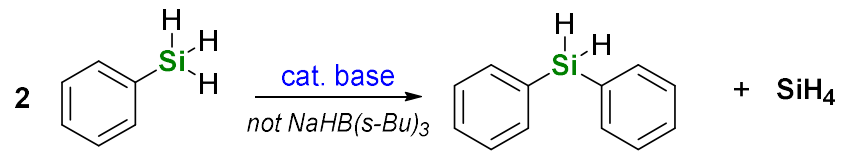

Scheme 2. Possible redistribution of phenylsilane reported under basic conditions.

On the basis of this observation, we postulate that tri(sec-butyl)borane, initially generated in the reaction of sodium tri(sec-butyl)borohydride with an alcohol, is formed as adduct and aids the catalytic 
reaction analogous to the one proposed by Schowen [41] in the form presented as example in Scheme 3. Another advantage of this system is the lack of external alkoxide which could lower the effective yield by contamination of products with other alkoxysilanes resulting from its presence.

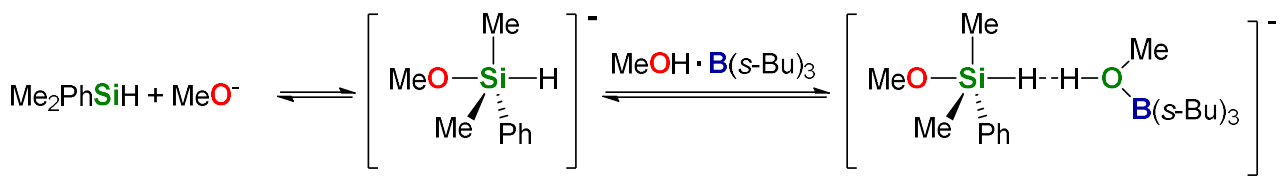

$$
\begin{aligned}
& \begin{array}{c}
\downarrow-\mathrm{H}_{2} \\
\mathrm{Me}_{2} \mathrm{PhSiOMe}+\left[\mathrm{MeO}-\mathrm{B}(\mathrm{s}-\mathrm{Bu})_{3}\right]^{-}
\end{array}
\end{aligned}
$$

Scheme 3. Proposed mechanism of tri(sec-butyl)borohydride-catalyzed direct dehydrogenative coupling of dimethylphenylsilane with methanol.

It seems very unlikely that any kind of hydride is effectively engaged in this catalysis in the presence of great excess of alcohol, contrary to what was proposed by Panda [32].

\section{Materials and Methods}

\subsection{General Remarks}

All reactions were performed under inert atmosphere. Oxygen does not seem to influence the performance, however, moisture is decreasing reactivity. Solvents were purified by distillation over sodium/benzophenone. Reagents (Sigma-Aldrich/Merck) were used as supplied, however, methanol, ethanol and benzyl alcohol were stored over molecular sieves.

Gas chromatography was performed on a Bruker Scion 436-GC with a $30 \mathrm{~m}$ Agilent VF5-ms $0.53 \mathrm{~mm}$ Megabore column and a thermal conductivity (TCD) detector. The temperature program was as follows: $60^{\circ} \mathrm{C}(3 \mathrm{~min}), 20^{\circ} \mathrm{C} / \mathrm{min}, 280^{\circ} \mathrm{C}(20 \mathrm{~min})$. NMR spectra were recorded on a Bruker Fourier 300 spectrometer and referenced to the solvent residual peak.

\subsection{Dehydrogenative Coupling of Alcohols with Silanes}

In a typical reaction, $1 \mathrm{mmol}$ of silane, and $1 \mathrm{mmol}$ of alcohol were placed in a Schlenk bomb flask dried and filled with argon. Next, $0.1 \mathrm{~mL}$ of $1 \mathrm{M}$ solution of sodium tri(sec-butyl)borohydride in THF was carefully added. Reaction vessel was closed and placed in a preheated oil bath at given temperature and stirred. Samples were taken at time intervals and analyzed using gas chromatography. After detection of complete conversion of substrates, reaction mixture was cooled down, dosed with approximately $3 \mathrm{~mL}$ of hexane, and left for $15 \mathrm{~min}$ to precipitate. The suspension was filtered and the resulting clear solution was evaporated to yield pure alkoxysilane.

\section{Conclusions}

Direct dehydrogenative coupling of alcohols with hydrosilanes can be efficiently promoted by sodium tri(sec-butyl)borohydride in solvent-free conditions, which enable almost quantitative isolation of desired alkoxysilane product.

Supplementary Materials: Spectral data of products are available online at http:/ /www.mdpi.com/2073-4344/ 8/12/618/s1. 1. Analytical data of isolated products, 2. Spectra of products.

Author Contributions: Conceptualization, M.Z. and M.S.; methodology, M.S.; validation, M.Z.; formal analysis, M.Z.; investigation, M.S., M.Z. and S.W.; writing—original draft preparation, M.Z.; writing—review and editing, M.S., SW and P.P.; supervision, P.P.; project administration, P.P.; funding acquisition, P.P.

Funding: This research and APC were funded by The National Science Centre (Poland), Grant No. UMO-2016/ 23/B/ST5/00177. 
Conflicts of Interest: The authors declare no conflicts of interest. The funders had no role in the design of the study; in the collection, analyses, or interpretation of data; in the writing of the manuscript, or in the decision to publish the results.

\section{References}

1. Pouget, E.; Tonnar, J.; Lucas, P.; Lacroix-Desmazes, P.; Ganachaud, F.; Boutevin, B. Well-Architectured Poly(dimethylsiloxane)-Containing Copolymers Obtained by Radical Chemistry. Chem. Rev. 2010, 110, 1233-1277. [CrossRef] [PubMed]

2. Hoffmann, F.; Fröba, M. Vitalising porous inorganic silica networks with organic functions-PMOs and related hybrid materials. Chem. Soc. Rev. 2011, 40, 608-620. [CrossRef] [PubMed]

3. Hoffmann, F.; Cornelius, M.; Morell, J.; Fröba, M. Mesoporöse organisch-anorganische Hybridmaterialien auf Silicabasis. Angew. Chem. 2006, 118, 3290-3328. [CrossRef]

4. Mizoshita, N.; Tani, T.; Inagaki, S. Syntheses, properties and applications of periodic mesoporous organosilicas prepared from bridged organosilane precursors. Chem. Soc. Rev. 2011, 40, 789-800. [CrossRef] [PubMed]

5. Sano, K.; Kanematsu, H.; Tanaka, T. Overview of silane-based polymer coatings and their applications. In Industrial Applications for Intelligent Polymers and Coatings; Springer International Publishing: Cham, Switzerland, 2016; pp. 493-509. ISBN 9783319268934.

6. Chang, C.W.; Lu, K.T. Organic-inorganic hybrid linseed oil-based urethane oil wood coatings. J. Appl. Polym. Sci. 2017, 134, 1-8. [CrossRef]

7. Xie, Y.; Hill, C.A.S.; Xiao, Z.; Militz, H.; Mai, C. Silane coupling agents used for natural fiber/polymer composites: A review. Compos. Part A Appl. Sci. Manuf. 2010, 41, 806-819. [CrossRef]

8. Dvornic, P.R.; Owen, M.J. Silicone Surface Science; Springer: Berlin, Germany, 2012.

9. Nihei, T. Dental applications for silane coupling agents. J. Oral Sci. 2016, 58, 151-155. [CrossRef]

10. Lalonde, M.; Chan, T.H. Use of Organosilicon Reagents as Protective Groups in Organic Synthesis. Synthesis (Stuttg) 1985, 1985, 817-845. [CrossRef]

11. Rücker, C. The Triisopropylsilyl Group in Organic Chemistry: Just a Protective Group, or More? Chem. Rev. 1995, 95, 1009-1064. [CrossRef]

12. Mekelburger, H.B.; Wilcox, C.S. 2.06 Formation of Enolates. In Comprehensive Organic Synthesis II; Elsevier: Amsterdam, The Netherlands, 2014; pp. 243-272, ISBN 9780080977430.

13. Chaudhary, S.K.; Hernandez, O. 4-Dimethylaminopyridine: An efficient and selective catalyst for the silylation of alcohols. Tetrahedron Lett. 1979, 20, 99-102. [CrossRef]

14. Kim, S.; Chang, H. 1,1,3,3-Tetramethylguanidine: An Effective catalyst for the t-butyldimethylsilylation of alcohols. Synth. Commun. 1984, 14, 899-904. [CrossRef]

15. Mukherjee, D.; Thompson, R.R.; Ellern, A.; Sadow, A.D. Coordinatively Saturated Tris(oxazolinyl)borato Zinc Hydride-Catalyzed Cross Dehydrocoupling of Silanes and Alcohols. ACS Catal. 2011, 1, 698-702. [CrossRef]

16. Ventura-Espinosa, D.; Sabater, S.; Carretero-Cerdán, A.; Baya, M.; Mata, J.A. High Production of Hydrogen on Demand from Silanes Catalyzed by Iridium Complexes as a Versatile Hydrogen Storage System. ACS Catal. 2018, 8, 2558-2566. [CrossRef]

17. Vijjamarri, S.; Chidara, V.K.; Rousova, J.; Du, G. Dehydrogenative coupling of alcohols and carboxylic acids with hydrosilanes catalyzed by a salen-Mn(v) complex. Catal. Sci. Technol. 2016, 6, 3886-3892. [CrossRef]

18. Gregg, B.T.; Cutler, A.R. $\mathrm{Mn}(\mathrm{CO}) 5 \mathrm{C}(\mathrm{O})-\mathrm{p}-\mathrm{C} 6 \mathrm{H} 5 \mathrm{CH} 3$-catalyzed hydrosilane $\mathrm{SiH} / \mathrm{SiD}$ exchange: Evidence from a kinetics study implicating coordinatively unsaturated manganese silyl intermediates. Organometallics 1993, 12, 2006-2009. [CrossRef]

19. Cardoso, J.M.S.; Lopes, R.; Royo, B. Dehydrogenative silylation of alcohols catalysed by half-sandwich iron N-heterocyclic carbene complexes. J. Organomet. Chem. 2015, 775, 173-177. [CrossRef]

20. Corbin, R.A.; Ison, E.A.; Abu-Omar, M.M. Catalysis by cationic oxorhenium(v): Hydrolysis and alcoholysis of organic silanes. Dalton Trans. 2009, 2850. [CrossRef]

21. Chung, M.-K.; Ferguson, G.; Robertson, V.; Schlaf, M. Nature of the active silane alcoholysis catalyst in the Ru w Cl x (CO) y (PMe 3) z (w, x, y, z = 1 or 2) system; Ru 2 ( $\mu-\mathrm{Cl}) 2 \mathrm{Cl} 2$ (CO) 4 (PMe 3) 2 as a new catalyst for silane alcoholysis in a polar solvent. Can. J. Chem. 2001, 79, 949-957. [CrossRef] 
22. Maifeld, S.V.; Miller, R.L.; Lee, D. Activation of silanes by Grubbs carbene complex Cl2(PCy3)2Ru CHPh: Dehydrogenative condensation of alcohols and hydrosilylation of carbonyls. Tetrahedron Lett. 2002, 43, 6363-6366. [CrossRef]

23. Garcés, K.; Fernández-Alvarez, F.J.; Polo, V.; Lalrempuia, R.; Pérez-Torrente, J.J.; Oro, L.A. Iridium-Catalyzed Hydrogen Production from Hydrosilanes and Water. ChemCatChem 2014, 6, 1691-1697. [CrossRef]

24. Field, L.D.; Messerle, B.A.; Rehr, M.; Soler, L.P.; Hambley, T.W. Cationic Iridium(I) Complexes as Catalysts for the Alcoholysis of Silanes. Organometallics 2003, 22, 2387-2395. [CrossRef]

25. Barber, D.E.; Lu, Z.; Richardson, T.; Crabtree, R.H. Silane alcoholysis by a nickel(II) complex in a N, O, S ligand environment. Inorg. Chem. 1992, 31, 4709-4711. [CrossRef]

26. Ohshita, J.; Taketsugu, R.; Nakahara, Y.; Kunai, A. Convenient synthesis of alkoxyhalosilanes from hydrosilanes. J. Organomet. Chem. 2004, 689, 3258-3264. [CrossRef]

27. Ito, H.; Watanabe, A.; Sawamura, M. Versatile dehydrogenative alcohol silylation catalyzed by $\mathrm{Cu}(\mathrm{I})$-phosphine complex. Org. Lett. 2005, 7, 1869-1871. [CrossRef] [PubMed]

28. Rendler, S.; Auer, G.; Oestreich, M. Kinetic Resolution of Chiral Secondary Alcohols by Dehydrogenative Coupling with Recyclable Silicon-Stereogenic Silanes. Angew. Chem. Int. Ed. 2005, 44, 7620-7624. [CrossRef] [PubMed]

29. Caseri, W.; Pregosin, P.S. Hydrosilylation chemistry and catalysis with cis-PtCl2(PhCH:CH2)2. Organometallics 1988, 7, 1373-1380. [CrossRef]

30. Ito, H.; Takagi, K.; Miyahara, T.; Sawamura, M. Gold(I)-Phosphine Catalyst for the Highly Chemoselective Dehydrogenative Silylation of Alcohols. Org. Lett. 2005, 7, 3001-3004. [CrossRef]

31. Weickgenannt, A.; Oestreich, M. Potassium tert -Butoxide-Catalyzed Dehydrogenative Si-O Coupling: Reactivity Pattern and Mechanism of an Underappreciated Alcohol Protection. Chem. Asian J. 2009, 4, 406-410. [CrossRef]

32. Harinath, A.; Bhattacharjee, J.; Anga, S.; Panda, T.K. Dehydrogenative Coupling of Hydrosilanes and Alcohols by Alkali Metal Catalysts for Facile Synthesis of Silyl Ethers. Aust. J. Chem. 2017, 70, 724. [CrossRef]

33. Gao, D.; Cui, C. N-Heterocyclic Carbene Organocatalysts for Dehydrogenative Coupling of Silanes and Hydroxyl Compounds. Chem. Eur. J. 2013, 19, 11143-11147. [CrossRef]

34. Blackwell, J.M.; Foster, K.L.; Beck, V.H.; Piers, W.E. B(C 6 F 5) 3-Catalyzed Silation of Alcohols: A Mild, General Method for Synthesis of Silyl Ethers. J. Org. Chem. 1999, 64, 4887-4892. [CrossRef] [PubMed]

35. Toutov, A.A.; Betz, K.N.; Haibach, M.C.; Romine, A.M.; Grubbs, R.H. Sodium Hydroxide Catalyzed Dehydrocoupling of Alcohols with Hydrosilanes. Org. Lett. 2016, 18, 5776-5779. [CrossRef] [PubMed]

36. Han, W.-S.; Kim, T.-J.; Kim, S.-K.; Kim, Y.; Kim, Y.; Nam, S.-W.; Kang, S.O. Silane-based hydrogen storage materials for fuel cell application: Hydrogen release via methanolysis and regeneration by hydride reduction from organosilanes. Int. J. Hydrogen Energy 2011, 36, 12305-12312. [CrossRef]

37. Zaranek, M.; Witomska, S.; Patroniak, V.; Pawluć, P. Unexpected catalytic activity of simple triethylborohydrides in the hydrosilylation of alkenes. Chem. Commun. 2017, 53, 5404-5407. [CrossRef] [PubMed]

38. Skrodzki, M.; Witomska, S.; Pawluć, P. Sodium triethylborohydride as a catalyst for the dehydrogenative silylation of terminal alkynes with hydrosilanes. Dalton Trans. 2018, 47, 5948-5951. [CrossRef] [PubMed]

39. Itoh, M.; Inoue, K.; Ishikawa, J.I.; Iwata, K. Disproportionation reactions of organohydrosilanes in the presence of base catalysts. J. Organomet. Chem. 2001, 629, 1-6. [CrossRef]

40. Kim, B.; Woo, H.-G. Dehydrocoupling, Redistributive Coupling, and Addition of Main Group 4 Hydrides. In Advances in Organometallic Chemistry; Academic Press: Cambridge, MA, USA, 2004; Volume 52, ISBN 9780120311521.

41. Howie, C.R.; Lee, J.K.; Schowen, R.L. Catalysis in organosilicon chemistry. IV. Proton inventory of the transition state for hydride expulsion from silicon. J. Am. Chem. Soc. 1973, 95, 5286-5288. [CrossRef]

(C) 2018 by the authors. Licensee MDPI, Basel, Switzerland. This article is an open access article distributed under the terms and conditions of the Creative Commons Attribution (CC BY) license (http:/ / creativecommons.org/licenses/by/4.0/). 